\title{
Impacts of the Thondaimanaru Barrage Construction on Socio - Economic Status of Fishing Communities in Thondaimanaru Lagoon, Jaffna, Sri Lanka
}

\author{
P Shobiya*, K Sivashanthini, S Sutharshiny, K Gunaalan \\ Department of Fisheries, Faculty of Science, University of Jaffna, Sri Lanka. \\ *Email: shobiyaparamasivam@gmail.com
}

\begin{abstract}
Present study was conducted to determine the impacts of barrage construction on livelihood status of fishers who involve fishing in Thondaimanaru lagoon. The data related to the socio - economic condition of fishers in the particular area were obtained through a pre - tested structured questionnaire and in - depth guided interviews from July 2016 to January 2017. Randomly selected 25 fishermen were interviewed. The collected data were subjected to descriptive statistical analysis. Survey results indicated that $88 \%$ of fishermen are living as nuclear families consisting of $4-5$ members. Majority of fishermen are Hindus and $92 \%$ are married. About $64 \%$ engaged in fishing are under age group of $36-55$. Education is still not prominent among the fishers. Only $84 \%$ has primary education. The main occupation in this society is fishing and earned highest monthly income LKR $(6000 \pm 1000)$. It was found that installation of barrage plays a crucial role in socio - economic status of fishers of Thondaimanaru lagoon. This barrage severely affected the traditional fishing, amount of fish production and its consequences on their income as well. It was apparent from the current study that these fishermen have poor livelihood status and they need support from government or other organizations to enhance their socio - economic status.
\end{abstract}

Keywords - Barrage, Livelihood, Socio - economics, Thondaimanaru lagoon

\section{INTRODUCTION}

The fisheries sector in Sri Lanka plays a vital role in economic and social life by providing direct and indirect employment opportunities for about 560,000 people and livelihoods for more than 2.7 million coastal communities (Fisheries industry outlook, 2016). In 2017, the share of fisheries to the Gross Domestic Production (GDP) of the country was $1.3 \%$ and the total fish production of the country was 531,310 metric tons (Central Bank of Sri Lanka, 2017). Socio - economic status is a measure of an individual's or family's economic and social position in relation to others, based on various variables responsible for that like income, education, occupation, family effluence, physical assets, social position, social participation, caste, muscle power, political influence, etc. (Reza et al., 2015).

In 1953 barrage with sluice gate was erected to prevent free flow of seawater into lagoon and gradually convert it to freshwater lake (Chitravadivelu, 1978). The installation of barrage plays a crucial role in socio - economic status of fisher folk of Thondaimanaru lagoon where it has thrown the traditional employment of fishermen and reduced the production of fish and their income. Prior to 1953 the lagoon provided employment and a livelihood for about 300 fishermen and their families, who netted approximately 150 tons per year (Chitravadivelu, 1978). But the introduction of the barrage with sluice gate has thrown nearly $2 / 3$ of the fishermen out of their traditional employment and bringing down the production of fish about 35 tons per year and disturbed the ecological equilibrium to such an extent that the fish fauna had been reduced from 47 species during 1967 1968 to about 15 species in 1978 and inadequate installation, lack of maintenance and poor operation procedures resulted in malfunctioning of the gates and leakage at barrage and changes in lagoon water salinity (Chitravadivelu, 1978). A baseline study carried out in Thondaimanaru lagoon, stated that presence of four fish species such as Chanos chanos, Hemirhamphus sp., Nematalosa sp. and Mugil cephalus and after construction of barrage, reduction of biodiversity was observed due to changes in rainfall pattern, salinity and depth (Piratheepa et al., 2016).

Most of the researchers feel that the conversion of fresh water lagoons shall make very big contribution to $70 \%-80 \%$ of the total requirement but the side effects of this conversion also has to be analyzed environmentally, socially and economically (Sivakumar, 2013). The lagoon converted as lake affected the livelihood of fishing community by lower their harvest and traditional employment. The small scale fisheries sector is mostly the livelihood occupation of the group of population within the extreme poverty that leads to a serious social, economic and political issue. Due to lack of knowledge in the socio - economic conditions of fishers and fishing communities, leads to poor planning and implementation of various fisheries management programs (Devi et al., 2012 \& 2016).

The present investigation is conducted to fulfil the objectives that is to identify the present status of socio - economic and livelihood profiles of involved fishermen and to find out some possible suggestions to improve livelihood status of fishermen. 


\section{MATERIALS AND MethodS}

\section{A. Study area}

The present study was carried out at Thondaimanaru (Figure 1) which is located in Jaffna district, Northern Province of Sri Lanka. Its geographical coordinates are $80^{\circ} 08^{\prime} \mathrm{E}-80^{\circ} 29^{\prime} \mathrm{E}$ and $9^{\circ} 34^{\prime} \mathrm{N}-9^{\circ} 49^{\prime} \mathrm{N}$ (Chitravadivelu, 1978) and covered with $75 \mathrm{~km}^{2}$ of surface area and $287 \mathrm{~km}^{2}$ of catchments area (Sivakumar, 2013). Majority of the population is involved in agriculture for income generation while fishing occupies the second place in livelihood activities. The study was carried out for seven month period from July 2016 to January 2017.

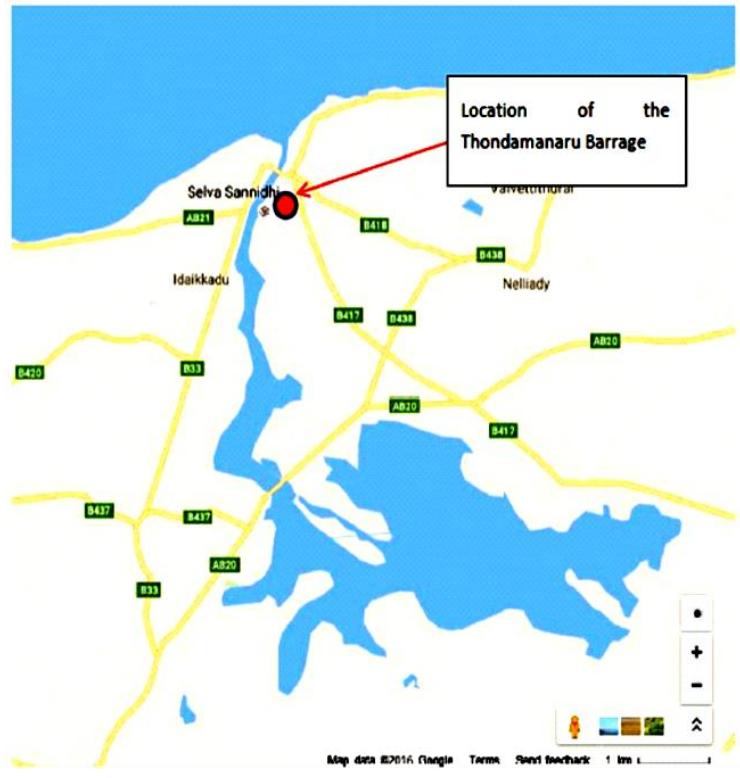

\section{2) Secondary data collection}

More detailed information related to socio - economic condition of fishers were collected from books, journals, thesis papers, Grama Niladari office and Thondaimanaru fishermen Co - operative society.

\section{Data analysis}

All the collected data were accumulated and analyzed by using Microsoft Excel analytical tool, version 2013. Results were

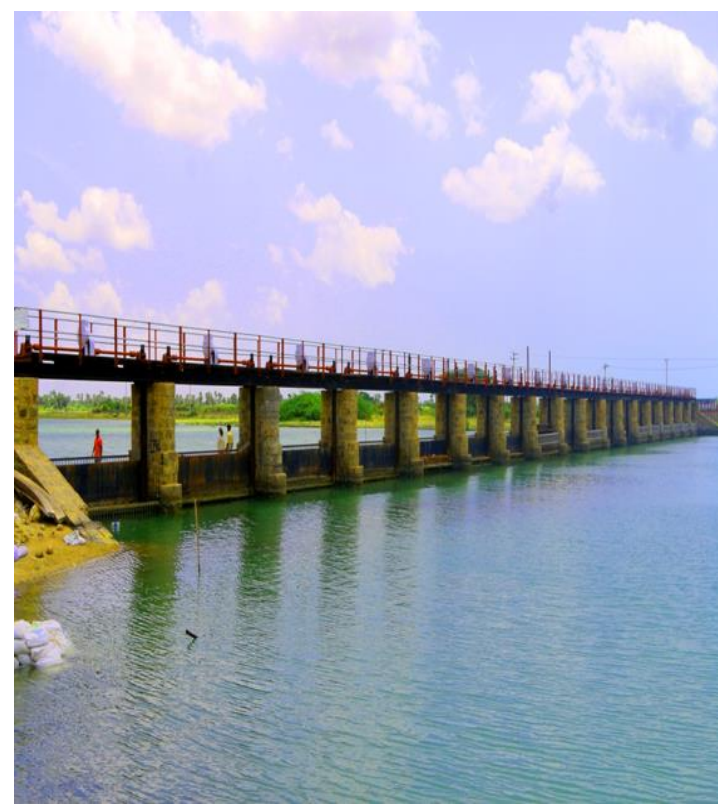

Figure 1. Map Location of barrage (Source: Google Earth) and existing barrage with sluice gate at Thondaimanaru lagoon

\section{B. Data collection}

Data were collected in two different methods such as primary and secondary data collection.

\section{1) Primary data collection}

The data related to the socio - economic condition of the fisher folk were obtained through structured questionnaire and in depth guided interviews to understand the fishermen's status earlier and present. Out of 50 active fishermen, a total of 25 were interviewed through field study at Thondaimanaru lagoon and fish market. The socio - economic profiles considered were family type, family size, religion, marital status, gender profile, age, education level, occupation and income. In addition, face to face interviews were carried out. Same questions were repeated for each fisherman. The interview engaged with three sections such as (1) questions related to their production of fishes earlier and after construction of barrage (2) Type of fisheries carried out by them and socio - economic status (3) questions related to loss of fish production and reduction of livelihood. All the participated interviews were informed and the collected data were kept confidential. presented in the form of textual, tabular and graphical forms to know about the present status of livelihood conditions of the fisher folk.

\section{RESULTS AND DISCUSSION}

The following socio - economic aspects were obtained in detail to show the impact of barrage construction on fisheries.

\section{A. Family Type}

Families are classified into two types: (1) Nuclear family: married couples with children and (2) Joint family: group of people related by blood and/or by law. A nuclear family consists of the members of two generations (parents and children) and joint family with members of three or more generations (Hossain et al., 2014). Hossain (2014) showed in his studies that 47 families were nuclear whereas only 3 were joint families which suits with the current investigation. In the survey area, it was found that $88 \%$ of people belonged to nuclear families and only $12 \%$ live as joint family (Figure $2 \mathrm{a}$ ). In general, changes in lifestyle determine the type of family. But in the study, it was identified that the construction of 


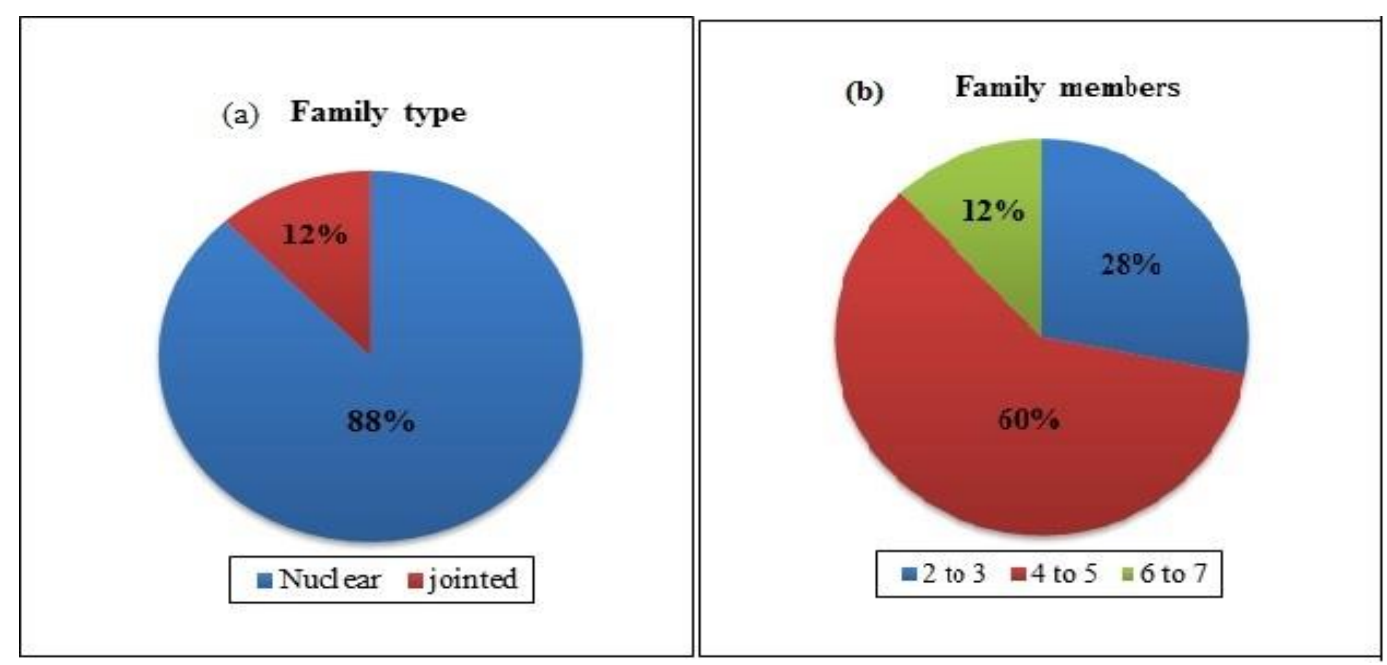

Figure 2. Family type (a) and family size (b) of fishermen of Thondaimanaru lagoon

barrage affected the status of fishing communities by means of their fishing activities and income as well. So they were not willing to have joint family which needs to be more financially staple to run their family.

\section{B. Family size}

The family size of fishermen was grouped into 3 categories such as 2 - 3 members (28\%), 4 - 5 members (60\%) and $6-7$ members $(12 \%)$. Most fishermen family belongs to $4-5$ members (Figure 2b).

\section{Religion}

In this study it was observed that most of the fishermen are Hindus (72\%) and $28 \%$ are Christians. Religion is a heritable human capital which plays a very important role in the social and cultural life of people of a particular area and can act as a notable constraint or modifies in social change (Reza et al., 2015). The most popular Selva Sannidhi Hindu temple is situated close to the study area and majority of fishermen are Hindus.

\section{Marital status}

In this survey it was found that, $92 \%$ were married and only $8 \%$ are unmarried. Majority of past findings highlight that most of active fishermen were married. Married fishermen resulted in a study by Ahamed (1996) which was 94\%, match with the present study.

\section{E. Gender profile in Fishing}

All the active fishers are male (100\%). Fishermen who involved in active fishing were male and female play a passive role in sorting, marketing, look after their household works and support their husband and family.

\section{F. Age structure}

The profile age (Figure 3) categorized as 15 - 35 (32\%), $36-55(64 \%)$ and $56-75(4 \%)$. The highest number of fishermen were in between 36 - 55 age groups. Similar study in Bangaladesh, resulted by Ahmed (1996) in Tangail and Ahmed (1999) in coastal region found that $66 \%$ and $70 \%$ fishermen were less than 40 years age, respectively. There is a negative perception in the society for fishers, which adversely affect the social reputation of the fishermen. In order to get a relief from the depressed mentality, they seek reputed occupations in the society other than fishing. Eventually that leads to low participation of the young in fishing activities (Ragavan et al., 2017). Although introduction of barrage severely diminished the amount of fish production and its consequences on their livelihood. Thus that made them less involvement of fishing activities in lagoon.

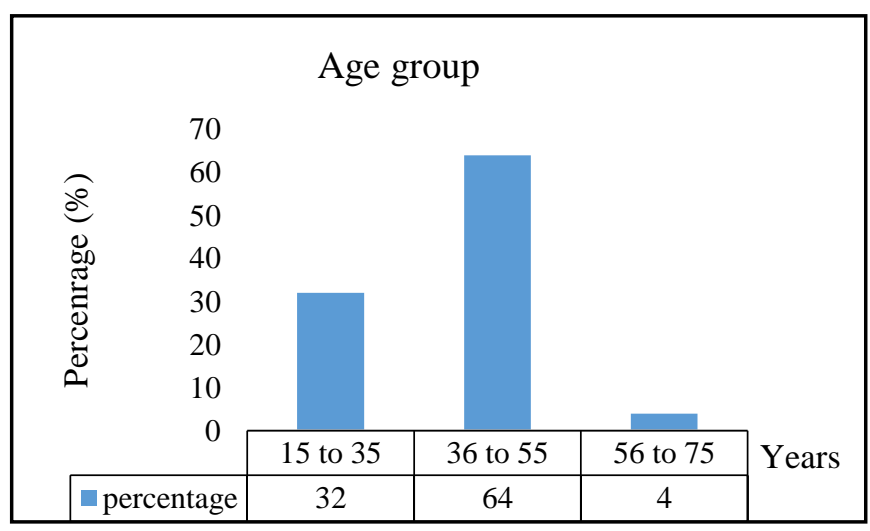

Figure 3: Age structure of Fishermen

\section{G. Literacy rate}

There is a strong relationship between social status and education. The higher is the education the better is the livelihood opportunities (Reza et al., 2015). Human resource development is largely a function of literacy and educational attainment. Amongst fishermen, literacy and education attainments help to develop conceptual skill and also facilitate the acquisition of technical skill which can have direct bearing on income generation, expenditure and saving activities (Abdullah Al Mamun, 2011). The studies revealed that 
majority of fishermen have primary education (84\%), $12 \%$ of secondary and 4\% with tertiary education respectively (Figure 4). Due to low income, lack of awareness and involvement in their traditional occupation may be the reasons for drops in educational status.

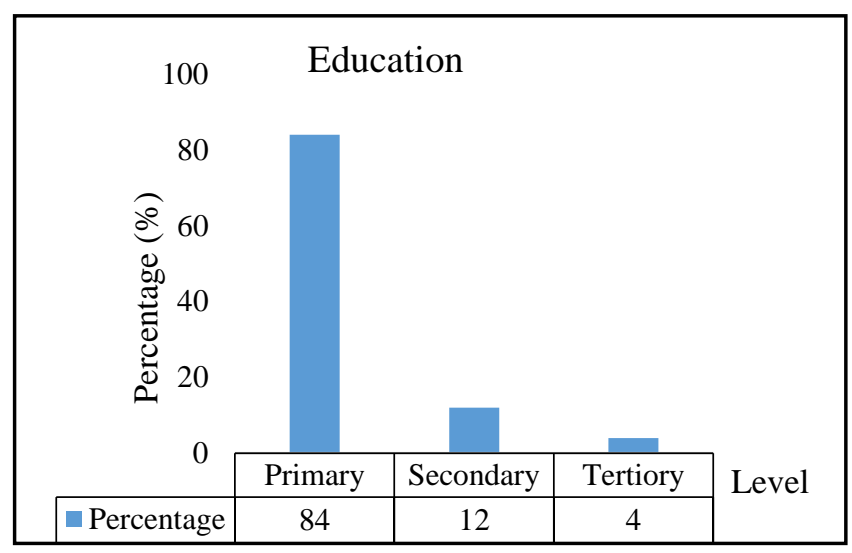

Figure 4: Educational status of Fishermen

\section{H. Occupation}

Fishing was the main occupation and $92 \%$ of fishermen were involved in fishing and remaining involved in agriculture and wage labour. After erection of northern barrage, more than 250 fisher families sacrificed their fishing opportunities (Chitravadivelu, 1978) and their living subsistence. As a result they have low harvest and income. Even they continue their traditional employment. But some of them shifted to other occupations or migrated to abroad.

\section{Income}

The fishermen who involved fishing in lagoon adopted traditional fishing methods, such as, cast net, sweep net and diving method. Fishermen use Kaddumaram as their vessel for fishing activity. The monthly Fishing income (Figure 5) in LKR < 3000 (24\%), $3000-6000(60 \%)$ and > $6000(16 \%)$. The highest fishing income is 3000 - 6000 LKR.

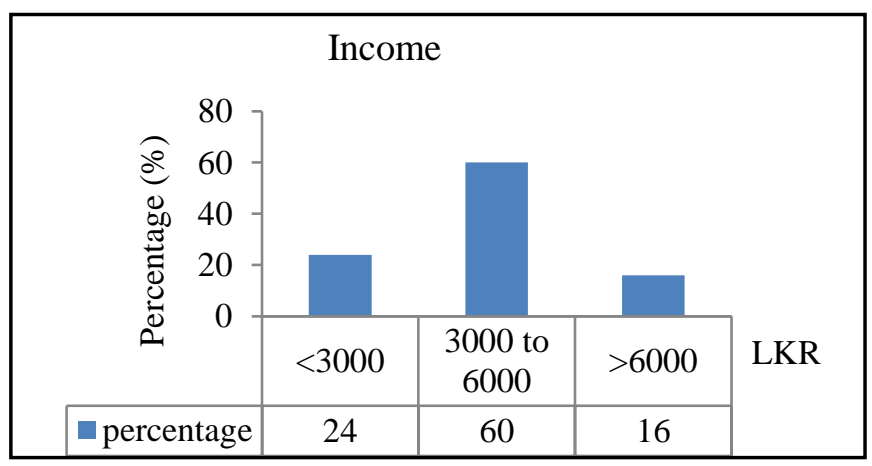

Figure 5: Income of Fishermen

The prime reasons for this condition are loss of production due to reduction of fish and shellfish species, still using the traditional fishing gears and technology, problems in marketing and lack of financial assistance.

\section{J. Reduction in biodiversity}

After development of barrage, it is serve as artificial barrier and prevents the recruitment of fish fauna from sea, lessen the yield and changes the water quality parameters of lagoon. Shobiya (2018) in a recent study, stated that the water quality parameters: Water temperature, Electric Conductivity, Total Dissolved Solids, Dissolved Oxygen, salinity and turbidity of Thondaimanaru lagoon significantly $(\mathrm{p}<0.05)$ vary with months. Change in lagoon water salinity is an important aspect that affects the availability and composition of aquatic resources and the livelihoods of the people who are depending on these resources (Sugirtharan et al., 2014). From the field survey it was found that changes in lagoon water salinity act as a reason for loss of fishery potentialities especially shrimps in Thondaimanaru lagoon where recruitment and development of shrimps get affected and complete depletion of shrimp harvest is observed recent three years, which altered the livelihood of fisher folk.

\section{K. Problems of Fishermen}

The following constraints were identified that have been faced by the fishers of Thondaimanaru lagoon:

- Reduction in biodiversity and production of fish and shell fish

- Low income

- Lack of support from government or any organizations

- Lack of awareness

- Following traditional fishing methods

- Lack of marketing facilities and financial assistance

\section{CONCLUSION}

The current study revealed that socio - economic status of fishermen of Thondaimanaru lagoon is poor. The socio economic and livelihood status of these fishermen is not satisfactory because fish production of natural source is declining day by day. Education is still not prominent among the fisher folk. Fishermen get very low income as loss of marine fisheries due to the installation of barrage. Government or other non - governmental organizations should encourage them and step forward to provide hands on training on freshwater fishery and initiate ways to develop freshwater fishery in lagoon by introducing highly valuable fish and shell fishes in the lagoon.

\section{ACKNOWLEDGEMENT}

We would like to express our heartfelt gratitude to fishers of Thondaimanaru lagoon for their corporation and providing valuable information to successfully complete this research project. 


\section{REFERENCES}

Abdullah Al Mamun. (2011). Socio-economic condition of fishermen in Kaptai Lake Area. M.Sc. thesis. Department of Aquaculture, Faculty of Fisheries, Bangladesh Agricultural University, Mymensingh.

Ahmed N. U. (1996). Report of the fishermen's socioeconomic survey. Fisheries survey and monitoring program. DoF, Tangail, 1 - 4.

Ahmed N. U. (1999). A study on socio-economic aspect of coastal fishermen in Bangladesh. MS Thesis, Dept. Aquacul., BAU, Mymensingh, Bangladesh.

Central Bank of Sri Lanka. (2017). Annual Report.

Chitravadivelu, K. (1978). Fishery Potentialities of the Thondaimanaru Lagoon and a way of developing it, Field Work Center Newsletter 9, 9 - 13.

Devi, N. B. L. Ngangbam, A. K. and Sheela, I. (2012). A study on existing fisheries management system and the problems faced by the fishers in Loktak Lake of Manipur. Journal of agriculture and veterinary science, 1(5), 22 - 28.

Devi, N. B. L. Ngangbam and Biswal, N. N., (2016). A review on the current fisheries management system in Manipur with special reference to Loktak Lake. Journal of agriculture and veterinary science, 7(4), 63 - 66.

Fisheries Industry Outlook. (2016). Socio - Economic and Marketing Research Division National Aquatic Resources Research and Development Agency.
Hossain, S. A. Z. Z. A. D., Hasan, M. T., Alam, M. T. and Mazumder, S. K., (2014). Socio - economic condition of the fishermen in jelepara under pahartoli of Chittagong district. J. Sylhet Agril. Univ, 1, 65 - 72.

Piratheepa, S., Rajendramani, G. and Eshwaramohan, T., (2016). Changes in fish and shellfishes in Thondamanaru lagoon, Jaffna,Sri Lanka, Journal of Animal and Vaterinary sciences, 3(6), $669-673$.

Ragavan, N., Sivashanthini, K. and Sutharshiny, S., (2017). Socio-economics status of fishermen of Allaipiddy village, Jaffna. Vingnanam Journal of Science, 12, 1 - 2.

Reza, S., Hossain, M.S., Hossain, U. and Zafar, M.A. (2015). Socio-economic and livelihood status of fishermen around the Atrai and Kankra Rivers of Chirirbandar Upazila under Dinajpur District. International Journal of Fisheries Aquatic Studies, 2, 402 - 408.

Sivakumar, S. S., (2013). Reclamation of Land and Improve Water Productivity of Jaffna Peninsula of Northern Sri Lanka by Improving the Water Quality of the Lagoons. Research Journal of Science and IT Management 2, 20 - 27.

Shobiya, P., Sivashanthini, K., Sutharshiny, S., and Gunaalan, K (2018). Variations in important water quality parameters and fish species of Thondaimanaru Lagoon , Jaffna, Sri Lanka, Vingnanam International Research Conference, 42.

Sugirtharan, M. Pathmarajah, S. and Mowjood, M. I. M. (2014). Variation of Salinity in Batticaloa Lagoon in Sri Lanka during Wet Season, Tropical Agricultural Research, 25(3), $403-411$ 
